\title{
Developing and validating an educational brochure to promote breastfeeding and the infant's complementary food
}

Nalu de Moraes Ribeiro 1

Ada Yukari Kanashiro Pereira 2

Ciléa Maria dos Santos Ozela 3

1-3 Santa Casa de Misericórdia do Pará. Rua Oliveira Belo, 395. Belém, PA, Brasil. CEP: 66.050-380. E-mail: nalumr93@gmail.com

\begin{abstract}
Objectives: to describe the stages of developing and validating two educational brochures to promote breastfeeding and the infant's complementary food.

Methods: an observational descriptive study was performed with eight health professionals and 60 caregiver of children under two years old divided into two groups of 30 (one for each brochure) in a Pediatric Outpatient Clinic at a Maternal and Child Reference Hospital. The research was developed in four stages: bibliographical survey, development of the brochures, validation by specialists and target audience and adequacy of the materials. The validation method used was the Índice de Validade de Conteúdo (Content Validity Index) calculation.

Results: two nutritional orientation brochures for infants were developed. Experts validated the breastfeeding brochure on its relevance and the brochure on complementary food regarding its relevance and goal. The other items were validated after suggested modifications. In relation to the target audience, the concordance index found in brochures 1 and 2 was higher than 75\%. The Índice de Validade de Conteúdo Global (Global Content Validity Index) of the materials was greater than 0.78 .

Conclusions: regarding its appearance and content after the adjustments, the brochures were considered valid by the experts and the representatives of the target audience.

Key words Pamphlets, Nutritional education, Breastfeeding, Complementary food, Validation study
\end{abstract}




\section{Introduction}

An adequate nutrition is considered an essential element for human being development, mainly in the early years of life. In this period, exclusive breastfeeding until the sixth month of life and the introduction of complementary food from that moment on are fundamental to ensure healthy growth and development, bearing in mind that at this age range the nutritional needs are elevated and food differs in a qualitative perspective in older children. ${ }^{1}$

Although the II Pesquisa de Prevalência de Aleitamento Materno (The Second Prevalence Research in Breastfeeding) took place in Brazilian capitals to show that there was an improvement in the median of breastfeeding duration, an increase of 10-months (in 1999) to 11.2 months (in 2008), the Pesquisa Nacional de Demografia e Saúde (National Demographic Health Survey) in 2006 showed a prevalence of $38.6 \%$ of exclusive breastfeeding. This result is still far from fulfilling the goal proposed by the World Health Organization (WHO) and the Ministry of Health (MH), that recommend the prevalence of exclusive breastfeeding up to the sixth month of life of at least $50 \%$ and the maintenance of breastfeeding until the second year of life or more.25

There is a consensus in the literature about complementary food for children under two years regarding the prevalence of inadequate feeding practices during this period, characterized by the presence of non-recommended food, such as ultraprocessed food as well as early food introduction. Due to this problem, the importance of health education in the scope of the Sistema Único de Saúde (SUS) (Public Health System) stands out. This could be considered as different learning practices that contribute to the individual's knowledge and behavioral changes. It should be emphasized that activities related to changes in eating habits involves nutritional education. $6-9$

Several printed educational materials, such as health care guides, brochures and booklets have been used as a common health education strategy in the Sistema Único de Saúde (SUS) (Public Health System), they can contribute positively for people in educational activities. However, the effectiveness of these instruments depend on the principles and the form of communication involved during its elaboration. 10

The bibliographic survey for the delimitation of the content, the choice of an accessible language, as well as the individuals' participation in the evaluation stage of the educational material are extremely important factors to ensure the elaboration of a good quality instrument, this material should be comprehensible, readable and attractive for the patient and the family. As a verbal orientation co-adjuvant for the infant and the caregiver, the use of printed educational material stands out as being a resource that guides the nutritionist during the nutritional assistance by contributing good growth and development for the infant. ${ }^{11}$

This research had as an aim to describe the development and validation stages of two nutritional orientation brochures, one to promote breastfeeding and another to promote the infant's complementary food.

\section{Methods}

This is an observational and descriptive study performed at a Maternal and Child Reference Hospital in the city of Belém, Pará State, which has as one of its purposes in assisting Child's Health and Woman's Health. The research venue was at a Premature Outpatient Clinic, where monitors the growth and development of premature infants with a multi-professional team in the areas of neuro-pediatrics, speech therapy, physiotherapy, occupational therapy, psychology, nutrition and nursing.

In the first stage of the study, a survey was performed online of scientific articles with the themes on breastfeeding, complementary food and validation of educational materials in health. Manuals and guides were also consulted from the Ministry of Health and from the Sociedade Brasileira de Pediatria (Brazilian Society of Pediatrics) in order to gather all pertinent information on the theme for the development of the brochure. $9,12,13$

After the research, the development stage of the brochures began, where the issues that constituted each educational material were defined and the illustrations were elaborated by a graphic designer, according to the researcher's guidelines regarding the layout and the illustrations format. The programs used for the edition of the figures were Adobe Photoshop Illustrator, Adobe InDesign and Corel draw software. After the development of the brochure, the validation was initiated by specialists and the target audience, and lastly the adequacy of the materials.

The participants' sample was carried out for convenience, that is, according to the outpatient care flow during the data collection period (April and May 2016), it was constituted by two groups, one was called the target audience, formed by caregivers 
of children under two years old and another was called the specialists, constituted of a multi-professional health team.

The target audiences' sample was comprised of 60 caregivers (30 individuals for each brochure), whose criteria for inclusion were: caregivers who were 18 years old or older and caregivers (mother, father, other relative or guardian) of the children in the age group from zero to less than two years old. Illiterates and those with visual impairment were excluded. The professionals with more than two years of experience in child nutrition or pediatrics were selected, eight specialists (two physicians, one nurse, three nutritionists and two speech therapists) were selected.

For the validation, two semi-structured and selfapplicable questionnaires were adapted from a previous study on the development and validation of an educational manual, 14 one of them was directed to the specialists, containing their demographic variables and questions related to the evaluation of the brochures organized into three topics (aim, structure and presentation), with the following options of answers: Inadequate, Partially adequate, Adequate and Totally adequate; the other questionnaire was used for validation by the target audience, containing their demographic variables and questions related to the evaluation of the brochure, divided into four topics (organization, writing style, appearance and motivation). In both instruments there was a space for suggestions in improving the material.

To validate the nutritional orientation brochure by the specialists, three strategies were used, according to the literature.14-16 The first one was considered a validated item when it obtained a classification of Totally Adequate by most of the specialists (half plus one of the number of specialists), and the other experts did not consider it Totally Inadequate. The item is also considered validated when the experts considered Partially Adequate or Inadequate, but the presented suggestions in improving were added to the instrument.

The second validation strategy of the item used the Índice de Validade do Conteúdo (IVC) ${ }^{15}$ (Content Validity Index), which measures the proportion or percentage of judges who are in agreement on a certain item of the instrument. The index score is calculated by the sum of the agreed items that are marked "Adequate or Totally Adequate" by the specialists, divided by the total number of answers. The items that received "Inappropriate or Partially Appropriate" were revised or deleted. To calculate the IVC Global instrument, that is, for the total evaluation of the brochure, the sum of all the
IVC calculated separately was used, dividing them by the number of items of the instrument. The agreement rate among the evaluators should be greater than or equal to 0.78 , as recommended in the literature. 16

To validate the nutritional orientation brochures by the target audience, the percentage of the absolute agreement was calculated, which consists of calculating the number of times the evaluators agreed and dividing it by the total number of the evaluations, ranging from 0 to $100 \%$. According to Stemler (2004), the item with the minimum agreement of $75 \%$ is considered valid. Values from $90 \%$ are considered high. 17

Microsoft Office Excel 2007 was used for database design, coding, typing and data analysis. The data were analyzed by means of descriptive statistics presented in frequencies, with absolute and relative numbers.

This study was submitted to the Research Ethics Committee at the Fundação Santa Casa de Misericórdia do Pará, and was approved according to the protocol number $1.463 .070 / 2016$. The participants who accepted to participate in the study, signed an Informed Consent Form, guaranteeing confidentiality of the information collected and the anonymity of the individual, following the Diretrizes e Normas Regulamentadoras de Pesquisa (Guidelines and Norms Regulating Research) involving human beings of the 466/12 Resolution from the Conselho Nacional de Saúde (National Health Council).

\section{Results}

The eight professionals evaluating the brochures were experienced specialists in neonatology and pediatrics in clinical and outpatient settings. The target audiences' socioeconomic and demographic profiles in brochure 1 and brochure 2 presented similarities: the children's mothers were housewives, from the Metropolitan Region of Belém city and had complete high school level. The mean age was 26.9 and 28.5 , respectively.

Two brochures on nutritional orientation for the infants were elaborated, one on breastfeeding (brochure 1) and the other on complementary food (brochure 2), designed for caregivers of infants with less than six months of age and infants over six months of age and less than two years of age, respectively (Figure 1).

Brochure 1 was composed of four pages and ten illustrations, divided into four topics addressing the following issues: advantages of breastfeeding for 


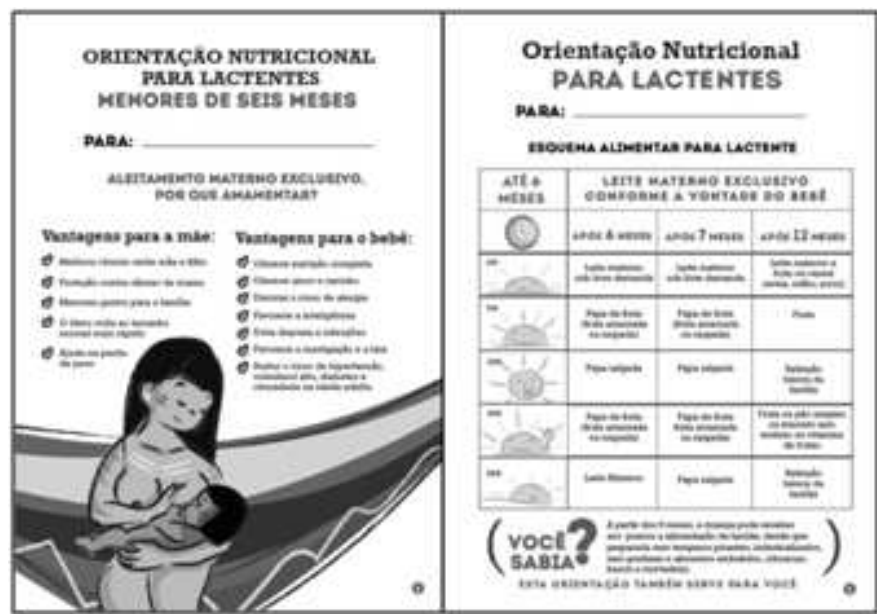

mother and baby; ten tips for a adequate handling; how should a breastfeeding mother's diet be?; how to remove and store breast milk?. Brochure 2 was composed of four pages and 32 illustrations, divided in four topics addressing the following issues: Infant food planning; learn how your baby's salty and sweet porridge composition should be; salty porridge (consistency and quantity); ten steps for a healthy diet for children under two years old.

Table 1 shows the distribution of the number of specialists according to the validation criteria (aim, structure and presentation, relevance) of the brochure 1 . All items in the relevance category were considered validated, since they presented an IVC greater than 0.78 . While in the aim, structure and presentation categories, items 1.3 and 2.2 received IVC $<0.78$ and the suggestions of improvement by the specialists were considered valid after the inclusion of the suggestions. Items $2.3,2.8,2.10$ and 3.4, although they presented an IVC $>0.78$, were considered partially adequate by one specialist, requiring modification in the brochure to receive validation. In addition, item 2.4 was not considered fully adequate by half plus one of the experts, but required adjustments. The IVC Global instrument was 0.93 , indicating an excellent level of agreement among the specialists.

Table 2 shows the distribution of the specialists according to the validation criteria (aim, structure and presentation, relevance) of brochure 2. All the items in the aim and relevance categories were considered validated, since they presented an IVC greater than 0.78 . While in the structure and presentation categories, item 2.2 received an IVC $<0.78$ requiring adjustments suggested by the specialists. Although, items 1.3, 2.1, 2.3, 2.8 and 3.4 had an IVC $>0.78$, they were considered partially adequate by one specialist, requiring modification in the brochure to receive a validation. In addition, item 2.10 was not considered fully adequate by half plus one of the specialists, also required modifications. The IVC Global instrument was 0.94 , indicating an excellent level of agreement among the specialists.

Table 3 shows the target audiences' evaluation and organization, writing style, appearance and motivation of brochures 1 and 2. All variables evaluated in both brochures were considered validated, since they obtained a concordance index higher than $75 \%$.

Regarding the adequacy of the nutritional orientation brochure, some items required modifications suggested by the specialists and the target audience to be validated, as shown in Table 4 . These suggestions sought to improve the understanding of the information and enriching the contents of the brochures. All the recommendations were adhered to, thus making these items validated. 
Distribution of the number of specialists according to validation criteria of the nutritional orientation brochure for infants under six months. Brazil, 2016.

1.Item

Validation

\begin{tabular}{llll}
\cline { 2 - 4 } & I PA A TA IVC \\
\hline
\end{tabular}

\section{Aim}

1.1 It is coherent for the caregivers' needs (mother, father, other relative, etc.).

1.2 It is coherent from the point of view for infants on eating healthy.

1.3 It can be used in scientific pediatric area.

$\begin{array}{cccc}- & 1 & 7 & 1 \\ - & - & 8 & 1 \\ 2 & 1 & 5 & 0.75\end{array}$

Structure and presentation

2.1 The educational brochure is appropriate to orient infants' caregivers.

2.2 The messages are presented in a clear and objective way.

2.3 The information presented is scientifically correct.

2.4 The material is appropriate for the sociocultural level of the proposed

target audience.

2.5 Logical sequence of the proposed content.

2.6 The information is well structured in agreement and spelling.

2.7 The writing style corresponds to the target audiences' level of knowledge.

2.8 The presentation of the information is coherent.

2.9 The sizes of the title and topics are adequate.

2.10 The illustrations are expressive and sufficient.

2.11 The number of pages is adequate.

Relevance

3.1 The themes represent key aspects that need to be strengthened.

3.2 The nutritional orientation proposes the learner to acquire knowledge about eating healthy.

3.3 The brochure approaches necessary issues for the caregiver to practice with the infants about eating healthy.

3.4 It is indicated for any health professional to use the brochure in their educational activities. 
Distribution of the number of specialists according to validation criteria of the nutritional orientation brochure for infants older than six months and younger than two years. Brazil, 2016.

Aim

1.1 It is coherent for the caregivers' needs (mother, father, other relative, etc.).

$1.2 \mathrm{It}$ is coherent from the point of view for infants on eating healthy.

1.3 It can be used in scientific pediatric area.

$\begin{array}{rrrrr}- & - & 1 & 7 & 1 \\ - & - & 1 & 7 & 1 \\ - & 1 & 1 & 6 & 0.88\end{array}$

Structure and presentation

2.1 The educational brochure is appropriate to orient infants' caregivers

2.2 The messages are presented in a clear and objective way.

2.3 The information presented is scientifically correct.

2.4 The material is appropriate for the sociocultural level of the proposed

target audience.

2.5 Logical sequence of the proposed content.

2.6 The information is well structured in agreement and spelling.

2.7 The writing style corresponds to the target audiences' level of knowledge.

2.8 The presentation of the information is coherent

2.9 The sizes of the title and topics are adequate.

2.10 The illustrations are expressive and sufficient.

2.11 The number of pages is adequate.

Relevance

3.1 The themes represent key aspects that need to be strengthened.

3.2 The nutritional orientation proposes the learner to acquire knowledge about eating healthy.

3.3 The brochure approaches the necessary issues for the caregiver to practice with the infants about eating healthy.

3.4 It is indicated for any health professional to use the brochure in their educational activities.

$\begin{array}{ccccc}- & 1 & 1 & 6 & 0.88 \\ - & 2 & 2 & 4 & 0.75 \\ - & 1 & 2 & 5 & 0.88 \\ - & - & 2 & 6 & 1 \\ & & & & \\ - & - & - & 8 & 1 \\ - & - & 1 & 7 & 1 \\ - & - & 2 & 6 & 1 \\ - & 1 & 1 & 6 & 0,88 \\ - & - & 1 & 7 & 1 \\ - & 1 & 3 & 4 & 0.88 \\ - & - & - & 8 & 1\end{array}$

IVC Global

I= Inadequate; PA= Partially Adequate; A= Adequate; TA= Totally Adequate; IVC= Índice de Validade de Conteúdo (Content Validity Index) in the development of the instrument for the infants' nutritional orientation by specialist judges. 
The target audiences' evaluation regarding organization, writing style, appearance and motivation on brochures 1 and 2 . Brazil, 2016

$\begin{array}{cc}\text { Brochure } 1 & \text { Brochure } 2 \\ \text { Option } 1 & \text { Option } 1\end{array}$

Option 1

$\begin{array}{llll}\mathrm{n} & \% & \mathrm{n} & \%\end{array}$

\section{Organization}

1.1 Did the presentation call your attention? 1.yes / 2.no

1.2 Does the issue show what they are referring to? 1.yes/2.no

1.3 Is the sequence of information adequate? 1.yes / 2.no

1.4 Is the amount of information adequate? 1.yes / 2.no

$\begin{array}{lccc}29 & 96.7 & 30 & 100.0 \\ 30 & 100.0 & 30 & 100.0 \\ 30 & 100.0 & 30 & 100.0 \\ 27 & 90.0 & 30 & 100.0\end{array}$

2. Writing Style

2.1 As for the understanding of the sentences, they are: 1. easy to understand / 29

2. difficult to understand

2.2 The written content is: 1 . clear / 2.confused

2.3 The text is: 1.interesting / 2.uninteresting

96.7

28

29

96.7

100.0

29

96.7

3. Appearance

3.1 The illustrations are: 1.simple / 2. Complicated

3.2 Do the illustrations complement the text? 1.yes / 2.no

$\begin{array}{lll}100.0 & 30 & 100.0\end{array}$

$\begin{array}{llll}30 & 100.0 & 30 & 100.0\end{array}$

3.3 Do the presentation of the text and figures seem organized? 1.yes / 2.no

30

$100.0 \quad 30$

100.0

\section{Motivation}

4.1 Anyone reading this nutritional orientation will understand what it is about? 1.yes / 2.no

4.2 Did you feel motivated to read to the end? 1.yes / 2.no

30

$100.0 \quad 29$

96.7

4.3 Does the brochure approach the issues that the caregiver needs (mother,

father, other relative, etc.) for children under 2 years of age? 1.yes / 2.no

4.4 Does the brochure propose to the caregiver's knowledge about eating healthy? 30

1.yes / 2.no

$\begin{array}{llll}29 & 96.7 & 30 & 100.0\end{array}$

$\begin{array}{llll}29 & 96.7 & 30 & 100.0\end{array}$

$\begin{array}{lll}100.0 & 30 \quad 100.0\end{array}$ 
Suggestions from the specialists and target audience, according to the evaluated category of brochures 1 and 2. Brazil, 2016.

\section{Brochure 1}

Aim

Item 1.3

Structure and presentation Items $2.2,2.3,2.4,2.8$ and 2.10

\section{Brochure 2}

Aim

Item 1.3

Structure and presentation

Items $2.1,2.2,2.3,2.8$ and 2.10

Relevance

Item 3.4
Include bibliographical references to the textual content.

Remove the phrase "improves quality of life."

Replace the term "develops" for "favors"

Replace the phrase "glass recipient with screw on lid" for " sanitized glass recipient with plastic lid."

Remove the term "sodium rich food."

Exemplify fatty foods (salty, fried and canned).

Explain why you cannot consume excessively some types of food.

Alternate the illustration of a mother breastfeeding, suggesting to place her in a more comfortable position.

Add an extended illustration representing the baby's handhold during breastfeeding.

Include bibliographical references to the textual content.

Include in the family's food orientation the phrase "non-fat and non-canned food."

Add some regional food in the cereals and vegetables group.

Include on the subtitle of the topic the number of spoons in the "Salty porridge - consistency and quantity".

Indicate mealtime under the topic "Infant Food Planning."

\section{The Target Audiences' Suggestions}

The change of the color on brochure 1 cover to more vivid colors.

Add the type of spoon that should be used in the salty porridge in brochure 2 . 


\section{Discussion}

The present study has resulted in more consistent educational tools, due to the contributions of the specialists and the target audience in the validation process. The participation of the target audience in the development of the educational materials was also valued by other researchers, ${ }^{10,18}$ since it allows the inclusion of contents in the brochure which met their needs and contributed to evaluate the understanding of the information. The group of specialists was composed of a multidisciplinary health team, considering that the validation of the content was performed by several professional categories permitted to have broad contributions, ensuring the quality of the proposed instrument. 19

Based on a bibliographical survey in selecting topics which were covered in the brochures, it demonstrated that an early interruption of exclusive breastfeeding is still predominant, mainly due to the lack of knowledge about breastfeeding and the procedures, breast intercurrences in the postpartum period and the advantages of breastfeeding. 20,21 These studies also showed mothers' misconceptions about the aspects of the complementary food, such as timing and the correct way of introducing food and the types of food to offer.20,21 Therefore, the development of the brochures contributes to the access of information that is essential for the infants' health by giving their caregivers knowledge on breastfeeding and the correct way to introduce the food.

In the validation of the brochures, the eight specialists consulted, indicated that both brochures are relevant tools to be used in the pediatrics departments and that brochure 2 has reached the purpose of meeting the caregivers' needs. Only two items from the aim, structure and presentation categories of brochure 1 and an item in brochure 2 presented an IVC $<0.78$, such data resembled to a finding in a study on development and validation of a self-care instrument for patients with diabetes mellitus type 2,22 in which only two items presented an IVC $<0.78$. The IVC Global values of brochures 1 and 2 found in this study (0.93 and 0.94 , respectively) were also similar to the study mentioned, whose value was found to be 0.98 .

The specialists' suggestions of this study related to the changes in the textual content corroborate with those demonstrated in Mendonça et a1.22 and Cruz et al., 23 study, in which grammatical modifications were suggested, such as the replacement of difficult words or terms to make reading clearer. In another study developed by Oliveira et al.,18 the judges presented suggestions to modify both the writing and the illustrations, as observed in this present study.

Regarding the validation by the target audience, although the studied brochures showed a concordance index greater than $75 \%$ in all the evaluation criteria (organization, writing style, appearance and motivation), some modifications were suggested in the illustration and the subtitle. Another study showed similar results when presenting a positive evaluation in all the criteria of an educational manual for the partners during labor and delivery and the target audience only suggested an alteration in the size of the titles. 14

The caregivers' validation of the brochure revealed that they were interested in reading, understood the information and accepted its appearance. Some of them even expressed their willingness to take the brochure home, which reinforces the quality and the necessity of the educational material. Cruz et al. 23 and Khurana et al.24 emphasize that the educational brochure does not substitute the health professional, but it works as a complementary guide and should be duly discussed with the target audience to ensure that they have understood the full purpose.

The language, layout and illustration were relevant aspects during the development of the material, since they ensure the readability and comprehension of the message and at the same time showed interest in reading. 25 Therefore, the development of the nutritional orientation brochures for infants sought to transmit the necessary information and it was easy to understand for the caregivers in order to guide them in promoting eating healthy food for the baby since birth up to two years of age.

The graphic designer was oriented regarding the organization and layout of the illustrations, seeking the easiness of understanding and the regionalization. The hiring of a professional expert in the area of design to elaborate educational technologies was also valued by other studies of validation, ${ }^{18,26}$ since it permits to demonstrate the originality of the material and graphic quality.

It was possible to observe during the development stage of the content of the brochures in which there are a few studies developed on validation of educational materials addressing the theme of breastfeeding and complementary food. A study by Moreira et al. 27 also showed that printed technologies such as brochures, posters, booklets or manuals are seldom submitted to a validation process due to the lack of knowledge of many health professionals about the method, resulting in the delivery of nontested or validated materials for the target audience.

Regarding the instruments used to evaluate 
educational materials, it was possible to observe that there is still no consensus in the literature about a specific validation standard. While some studies used a qualitative approach such as a focus group technique and content analysis, others have used the quantitative content validity index method. ${ }^{18}$

One of the limitations of this study refers to the external validation of the instruments in other regions of the country, the necessity to adjust for a better understanding of the information, since the materials present figures that refer to the daily life of the local culture, such as the figure of a woman breastfeeding sitting on a hammock and food examples from the North Region, in order to facilitate the target audiences' understanding served by the Public

\section{References}

1. Lima DB, Silva MMS, Paula HAA, Ribeiro RCL, Alfenas RCG. Alimentação na primeira infância no Brasil. Rev APS. [periódico online]. 2012 [acesso em 29 set 2015]. 15: 336344p. Disponível em: https://aps.ufjf.emnuvens.com.br/ aps/article/view/634/664

2. Brasil. Ministério da Saúde. II Pesquisa de Prevalência de Aleitamento Materno nas Capitais Brasileiras e Distrito Federal. Ministério da Saúde, Secretaria de Atenção à Saúde, Departamento de Ações Programáticas e Estratégicas. Brasília, DF; 2009

3. Brasil. Ministério da Saúde. Avaliação da atenção ao prénatal, ao parto e aos menores de um ano na Amazônia Legal e no Nordeste, Brasil, 2010. Ministério da Saúde, Secretaria de Ciência, Tecnologia e Insumos Estratégicos, Departamento de Ciência e Tecnologia. Brasília, DF; 2013.

4. Brasil. Ministério da Saúde. Pesquisa Nacional de Demografia e Saúde da Criança e da Mulher - PNDS 2006: dimensões do processo reprodutivo e da saúde da criança/ Ministério da Saúde, Centro Brasileiro de Análise e Planejamento. Brasília, DF; 2009

5. WHO. UNICEF. Global Nutrition Targets 2025 : Breastfeeding policy brief. WHO/NMH/NHD/14.7; 2014

6. Santos Neto ET, Farias CP, Barbosa ML, Oliveira AE, Zandonade E. Associação entre consumo alimentar nos primeiros meses de vida e condições socioeconômicas: um estudo longitudinal. Rev Nutr. 2009; 22: 675-85.

7. Caetano MC, Ortiz TTO, Silva SGL, Souza FIS, Sarni ROS. Alimentação complementar: práticas inadequadas em lactentes. J Pediatr. (Rio J). 2010; 86 (3): 196-201.

8. Saldiva SRDM, Venancio SI, Gouveia AGC, Castro ALS, Escuder MML, Giugliani ERJ. Influência regional no consumo precoce de alimentos diferentes do leite materno em menores de seis meses residentes nas capitais brasileiras e Distrito Federal. Cad Saúde Pública. 2011; 27: 2253-62.

9. Souza FIS, Caetano MC, Ortiz TT, Silva SGL, Sarni ROS Alimentação complementar de lactentes no primeiro ano de vida: ênfase nas papas principais. RevAssocMed Bras. 2014. 60: 231-5.
Health System. Another limitation of the present study refers to the reduced number of studies on validation of educational materials, compromising a deeper discussion of the results.

This study described the development and validation steps of two nutritional orientation brochures. It is expected that the brochures will be used by the outpatient care clinic as a tool for nutritional education, as it will bring benefits to the infants' caregivers regarding breastfeeding and the introduction of complementary food. Considering the changes in knowledge in the area of child nutrition, it is proposed to carry out periodic updates of the content of the instruments, according to the scientific innovations and the target audiences' needs.

10. Reberte LM, Hoga LAK, Gomes ALZ. O processo de construção de material educativo para a promoção da saúde da gestante. RevLat-am Enfermagem. 2012; 20 (1).

11. Echer IC. Elaboração de manuais de orientação para o cuidado em saúde. Rev Latino-am Enfermagem. 2005; 13: 754-7.

12. Brasil. Ministério da Saúde. Dez passos para uma alimentação saudável: guia alimentar para crianças menores de dois anos: um guia para o profissional da saúde na atenção básica. 2 ed. Brasília, DF; 2010.

13. Sociedade Brasileira de Pediatria.Manual de orientação para a alimentação do lactente, do pré-escolar, do escolar, doadolescente e na escola/Sociedade Brasileira de Pediatria. Departamento de Nutrologia,3 ed. Rio de Janeiro, RJ: SBP, 148 p; 2012.

14. Teles LMR, Oliveira AS, Campos FC, Lima TM, Costa CC, Gomes LFS, Oriá MOB, Damasceno AKC. Construção e validação de manual educativo para acompanhantes durante trabalho de parto e parto. RevEscEnferm USP. 2014; 48: 977-84.

15. Polit DF, Beck CT. The content validity index: are you sure you know what's being reported? Critique and recomendations. Res Nurs Health. 2006;29: 489-97.

16. Alexandre NMC, Coluci MCO. Validade de conteúdo nos processos de construção e adaptação de instrumentos de medida. Ciênc Saúde Coletiva. 2011; 16: 3061-8.

17. Matos DAS. Confiabilidade e concordância entre juízes: aplicações na área educacional. Est Aval Educ. 2014; 25 : 298-324

18. Oliveira SC, Lopes MVO, Fernandes AFC. Construção e validação de cartilha educativa para alimentação saudável durante a gravidez.Rev Latino-Am Enfermagem. 2014; 22: 611-20.

19. Paim EA, Nascimento ERP, Bertoncello KCG, Sifroni KG, Salum NC, Nascimento KC. Validação de instrumento para intervençãode enfermagem ao paciente em terapia vasoativa.RevBrasEnferm. 2017;70:476-84. 
20. Martins ML, Haack A. Conhecimentos maternos sobre alimentação complementar: introdução dos alimentos, avaliação e identificação das dificuldades observadas em uma Unidade Básica de Saúde. Com Ciências Saúde. 2012; 23:353-9.

21. Amaral LJX, Sales SS, Carvalho DPSRP, Cruz GKP, Azevedo IC, Ferreira Júnior MA. Fatores que influenciam na interrupção do aleitamento materno exclusivo em nutrizes. Rev Gaúcha Enferm. 2015; 36(esp):127-34.

22. Mendonça SCB, Zanetti ML, Sawada NO, Barreto IDC, Andrade JS, Miyar LO. Construção e validação do Instrumento Avaliação do Autocuidado para pacientes com diabetes mellitus tipo 2. Rev Latino-Am Enfermagem. 2017; 25:e2890

23. Cruz FOAM, Ferreira EB, Vasques CI, Mata LRF, Reis PED. Validação de manual educativo para pacientes com câncer de cabeça e pescoço submetidos à radioterapia. Rev Latino-Am Enfermagem. 2016. 24: e2706.
24. Khurana S, Rao BK, Lewis LES, Bhat R, Purkayastha J, Kamath A, Dharmaraj SK. Development and Validation of Educational Leaflet for Caregivers of Preterm Infants. J Clin Diag Res. 2016;10: YC01-YC04.

25. Moreira MF, Nóbrega MML, Silva MIT. Comunicação escrita: contribuição para a elaboração de material educativo em saúde. RevBrasEnferm. 2003; 56: 184-8.

26. Cordeiro LI, Lopes TO, Lira LEA, Feitoza SMS, Bessa MEP, Pereira MLD, Feitoza AR, Souza AR. Validação de cartilha educativa para prevenção de HIV/Aids em idosos.RevBrasEnferm. 2017; 70:808-15.

27. Moreira APA, Sabóia VM, Camacho LF, Daher DV, Teixeira E. Jogo educativo de administração de medicamentos: um estudo de validação.RevBrasEnferm. 2014; 67:528-34.
Received on February 7, 2017

Final version submitted on January 28, 2018

Approved on March 2, 2018 